\title{
20 years of Congressional Fellows- looking back and ahead
}

\author{
2016-2017 MRS/OSA and MRS/TMS Congressional Fellowship \\ Application Period Begins • www.mrs.org/congressional-fellows
}

$\mathrm{O}^{\prime}$ ne morning in late August, 16 professionals greeted each other at a Washington, DC, restaurant. Behind the table where they gathered, the large window framed the US Capitol Building in the distance. This was the annual gathering of alumni of the Congressional Science and Engineering Fellowship Program sponsored by the Materials Research Society (MRS) with the Optical Society of America (OSA) and The Minerals, Metals and Materials Society (TMS). The group had come together to welcome to town the two incoming fellows, MRS/OSA Fellow Peter Winter and MRS/TMS Fellow Jeremy Ward.

Later that day, Winter and Ward would attend the first day of a twoweek orientation run by the American Association for the Advancement of Science, which administers the fellowship program. That orientation would lead to an interview process and the positions in government they would hold for the next 12 months. But for now, the two had the chance to hear experiences

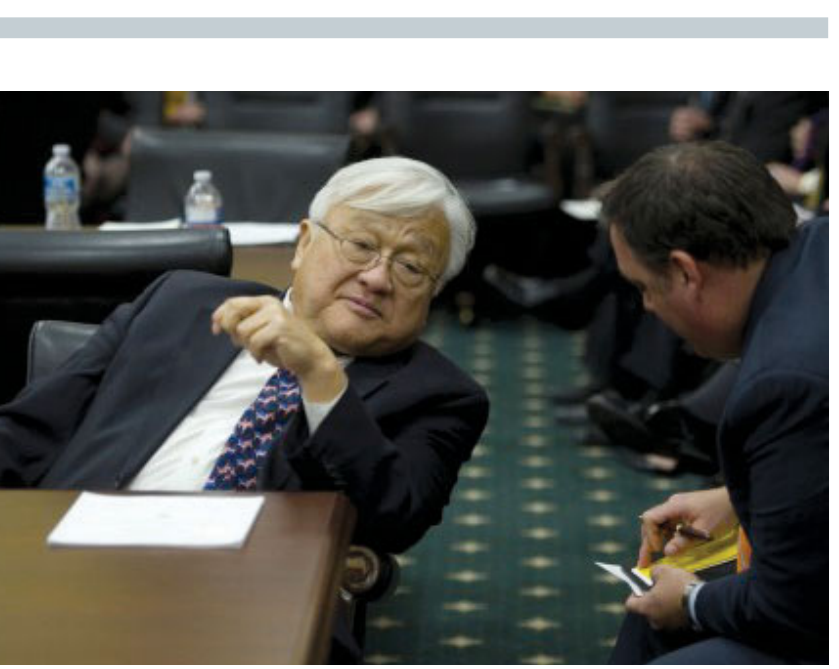

Eric Werwa (right) - former MRS/OSA Congressional Fellow, now on staff-briefs Congressional representative Mike Honda (Calif.). and ask questions of the MRS/OSA and MRS/TMS Fellows who preceded them.

This year marks the 20th anniversary of the involvement of MRS in the fellowship program, and the special network of former fellows has been in place from the beginning. "The network is unique to MRS in the fellowship program," says former Fellow and MRS Government Affairs Committee chair Kevin Whittlesey. "It was the brainchild of Kelly Kirkpatrick, who was the very first MRS/OSA Fellow in 1995. She reached out to the second incoming MRS/ OSA Fellow, Michal Freedhoff, and the tradition of support was formed and maintained. And it's stronger than ever now."

That network comprises 26 former fellows who have gone on to careers in policy, academia, industry, start-ups, nonprofits, and consulting. To this day, they maintain extensive networks across Capitol Hill from their own fellowship years, and have considerable experience to share. "Many former fellows wanted to attend this meeting, but not everyone's schedule would permit it," Whittlesey says. "However, they are all committed to be part of the fellowship network."

And while new fellows are preparing for their year, the application period for the 2016-2017 MRS/ OSA and MRS/ TMSFellowships is already beginning.

MRS entered the fellowship program at a key point in the rec- ognition of the critical role of science in policy. In the early $1990 \mathrm{~s}$, both the George H.W. Bush and Bill Clinton administrations were prioritizing and funding science for transportation, communications, infrastructure, and the environment and encouraging collaboration and science literacy.

Former MRS president Elton Kaufmann proposed the fellowship program to the MRS leadership. The program was designed, he explains, to further the effective use of scientific and technical knowledge in government and to help educate the scientific and engineering community on the public policy process. MRS established a partnership with OSA, and over the next three years, successive MRS presidents Tom Picraux, John Bravman, and Julia Phillips worked to ensure the successful selection of the first MRS/OSA Fellow in 1995. MRS partnered with TMS on a second fellowship in 2008.

Since then, MRS/OSA and MRS/TMS Fellows have been involved in helping to advance the role of science in policy and funding initiatives in virtually every facet of government, including defense; energy; science, technology, engineering and mathematics; and technology transfer.

"They have given science a voice at the table so policymakers know the impact of their decisions," Whittlesey says.

Policymakers and their staff have the opportunity to learn broadly about science. Former Fellow Jennifer Nekuda Malik recalled hosting staff briefings on topics ranging from exascale highperformance computing to the discovery of the Higgs boson.

The dividends for society continue well after the fellowship year wraps up. "Many of the former fellows are enmeshed in the political process today," remarks Ron Kelley, retired director of the MRS Office of Public Affairs. Michal Freedhoff 


\section{MRS/OSA and MRS/TMS Congressional Science and Engineering Fellows}

\begin{tabular}{|c|c|c|c|}
\hline Fellowship & Fellow & Fellow Placement & Current Employer \\
\hline 2014-2015 MRS/OSA & Jimmy O'Dea & Sen. Brian Schatz & TBD \\
\hline 2014-2015 MRS/TMS & Adria Wilson & Sen. Bernie Sanders & $\begin{array}{l}\text { ORISE Fellow at DOE Fuel Cell } \\
\text { Technologies Office }\end{array}$ \\
\hline 2013-2014 MRS/OSA & Sydney Kaufman & Sen. Mark Begich & AAAS Fellow/US Dept. of State \\
\hline 2013-2014 MRS/TMS & Megan Brewster & Senate Energy \& Natural Resources & AAAS/ORISE \\
\hline 2012-2013 MRS/OSA & Mirvat Abdelhaq & Sen. Jeff Merkley & USAID \\
\hline 2012-2013 MRS/TMS & Drew Steigerwald & Sen. Sherrod Brown & $\begin{array}{l}\text { DOE Advanced } \\
\text { Manufacturing Office }\end{array}$ \\
\hline 2011-2012 MRS/OSA & Laura Povlich & Rep. Sander Levin & NIH Fogarty International Center \\
\hline 2011-2012 MRS/TMS & Jennifer Nekuda Malik & Senate Energy \& Natural Resources & Self-employed Writer \\
\hline 2010-2011 MRS/OSA & Ashley White & Sen. Al Franken & $\begin{array}{l}\text { Lawrence Berkeley } \\
\text { National Laboratory }\end{array}$ \\
\hline 2009-2010 MRS/OSA & Gavi Begtrup & Rep. Gabrielle Giffords & Eccrine Systems \\
\hline 2009-2010 MRS/TMS & Ed Herderick & Sen. Sherrod Brown & $\begin{array}{c}\text { GE Advanced } \\
\text { Manufacturing Initiative }\end{array}$ \\
\hline 2008-2009 MRS/OSA & Amit Mistry & Rep. Edward Markey & USAID \\
\hline $\begin{array}{l}\text { 2008-2009 } \\
\text { MRS/TMS/ACERS }\end{array}$ & Ticora Jones & Sen. Russell Feingold & USAID \\
\hline 2007-2008 MRS/OSA & Alicia Jackson & Senate Energy \& Natural Resources & Drawbridge Health \\
\hline 2006-2007 MRS/OSA & Kevin Whittlesey & Rep. Doris Matsui & $\begin{array}{l}\text { CA Institute for } \\
\text { Regenerative Medicine }\end{array}$ \\
\hline 2005-2006 MRS/OSA & Ben Gross & Rep. Rush Holt & Apple, Inc. \\
\hline 2004-2005 MRS/OSA & Karin Ezbiansky Pavese & Sen. Joseph Lieberman & KEP Consulting \\
\hline 2003-2004 MRS/OSA & Colin McCormick & Rep. Edward Markey & Global Green Growth Institute \\
\hline 2002-2003 MRS/OSA & Jeff Haeni & Rep. Rush Holt & USAID \\
\hline 2001-2002 MRS/OSA & Eric Werwa & Rep. Mike Honda & Rep. Mike Honda \\
\hline 2000-2001 MRS/OSA & Sue Ginsberg Hamm & Rep. Howard Berman & $\begin{array}{l}\text { NSF/Directorate for Mathematical } \\
\text { and Physical Sciences }\end{array}$ \\
\hline 1999-2000 MRS/OSA & Arun Seraphin & Sen. Joseph Lieberman & $\begin{array}{l}\text { Senate Armed Services } \\
\text { Committee }\end{array}$ \\
\hline 1998-1999 MRS/OSA & Merrilea Mayo & Sen. Joseph Lieberman & Mayo Enterprises LLC \\
\hline 1997-1998 MRS/OSA & Brian Holloway & Sen. John Rockefeller & $\begin{array}{l}\text { Lockheed Martin } \\
\text { Advanced Technology Lab }\end{array}$ \\
\hline 1996-1997 MRS/OSA & Michal Freedhoff & Rep. Edward Markey & Sen. Edward Markey \\
\hline 1995-1996 MRS/OSA & Kelly Kirkpatrick & Sen. Joseph Lieberman & Self-employed \\
\hline
\end{tabular}

Applications for the 2016-2017 MRS/OSA Congressional Science and Engineering Fellowship Program are now being accepted. Deadline for submission is January $\mathbf{8 , 2 0 1 6}$. To learn more about the Fellowship Program and how you can apply, visit www.mrs.org/congressional-fellows. 
is now director of oversight and investigations for Senator Edward Markey, Eric Werwa is deputy chief of staff/legislative director for Congressional representative Mike Honda, and Arun Seraphin is a professional staff member on the Senate Armed Services Committee. "These careers and those of many of the other former fellows likely would not have proceeded in these directions without their fellowships," Kelley says.

As a Society, MRS has also benefited from the fellows in their subsequent volunteer service. For example, completing their fellowships, Whittlesey and Gavi Begtrup have served regularly on the MRS Government Affairs Committee. Eric Werwa and Brian Holloway have also led the MRS Fellow Subcommittee, and Holloway ran an alternative careers forum at a MRS Meeting. Ashley White serves on the Government Affairs Policy Subcommittee and is organizing the 2016 MRS Spring Meeting symposium "Materials for Sustainable Development-Integrated Approaches." Merrilea Mayo served on numerous MRS committees and as MRS president in 2003. Such service extends also to MRS partner societies. Former Fellow Ed Herderick serves on the TMS Board and as a trustee of the TMS Foundation.

"Service of the fellows to MRS is largely unique in the [professional] society world," says Damon Dozier, MRS director of government affairs. "Much of it was made possible by MRS reaching out to engage past fellows in Society activities and the dedicated support system provided by the former fellows."

"MRS got the balance exactly right," Holloway adds. "They stayed engaged with the fellows for support and welcomed their input, all the while not influencing policy through the fellows."

"And from the fellows' point of view, the whole fellowship experience is transformational," says Begtrup, currently chair of the MRS Government Affairs Committee.

Freedhoff agrees. "You go into the fellowship with a fairly narrow view of what science policy is, such as funding for R\&D," she says. "And then you see how science also influences other areas, such as the safety of chemicals in commerce and telecommunications and cyber-security."

The fellows learned how the policymaking process works, how busy the members of Congress are, and how much they rely on their staff.

"One of the biggest things I learned," Nekuda Malik says, "is how many people play a role in any piece of legislation. The staff members typically are in charge of drafting the legislation; however, they often work with other Hill staffers, agencies, stakeholders, and the general public to make sure the legislation addresses the relevant issues."

The fellows all agree that they learned a great range of communications skills from drafting memos, statements, speeches, and letters, to preparing legislation.

"And I learned a different measurement of "productivity," says Megan Brewster. "Sometimes you are simply moving policy forward in a way that might not materialize until sometime in the future."

Jimmy O'Dea, who completed his MRS/OSA Fellowship this fall, sees a connection back to the laboratory. "It makes you a better scientist," he says. "It gives you perspective on how your research fits into the larger scientific enterprise and national economy."

Holloway benefited upon his return to academia. "I understood the appropriations cycle and better understood the world of the program managers and what they needed. It made me more successful at obtaining funding." He says this knowledge also carries over to his career in industry.

And many of the fellows acquired enormous technical expertise in special areas, says Kelley, citing Freedhoff's work in energy and Seraphin's involvement in armed services and defense.

"The program is the best career accelerator possible, period," Herderick says. "It's a highlight of your resume and differentiates you."

Although many fellows served directly out of graduate school, midcareer scientists can be extraordinarily effective fellows and reap personal benefits in unexpected ways.

Mayo had been in academia for seven years when she applied for the fellowship.
"The advantage for me as a mid-career fellow was that I actually knew how things worked," she says. "I could explain the impact that funding decisions had on the scientist in the lab." Ken Lutz, who participated as an IEEE Fellow after a three-decade career in industry agrees. "I applied for a fellowship because I felt it was my time to give back," he says. "But I didn't expect to learn as much as I did. It entirely opened my eyes. The fellowship completely changed my career direction." Lutz went on to design and teach a pioneering university course on the smart grid.

"Scientists at any career stage are encouraged to apply for the fellowships," Begtrup says. "Anyone who's passionate about how policy affects science or the pace of science and technology would find the fellowship to be a great experience."

"The fellowship program is a critical investment in the future," Dozier says. He enumerated a short list of current issuesbasic and applied research funding, climate change, smart manufacturing, advanced manufacturing, and critical minerals.

"And it's a different type of budget crisis than seen in the past 10 or 20 years," Seraphin says. "There are enormous challenges ahead."

At the restaurant meeting, text messages signaled the day's other obligations, and the old and new friends began to disperse. The gathering made a lasting impression on the new fellows. "One of my goals for the year is to develop my personal relationships with academics and policymakers/advisers at the crossroads of science and policy," Ward says. "The opportunity to meet with former MRS/OSA and MRS/TMS Fellows informally was a great way to begin." Winter agrees. "This alumni community is a willing and valuable resource for me as an incoming fellow," he says. "It's clear that they love what they do, and credit their fellowship years for helping them get to where they are now."

Outside the weather was now $88^{\circ} \mathrm{F}$ and humid. And despite a rainy forecast, the clouds were breaking up. It was beginning to look like a pleasant day in the nation's capital.

Gail Oare 